\title{
Effects of tripelennamine and pentazocine alone and in combination on fixed-ratio responding of rats
}

\author{
DEBORAH GROSSETT, SCOTT WALLACE, MITCHELL PICKER, and ALAN POLING \\ Western Michigan University, Kalamazoo, Michigan
}

The effects of tripelennamine $(3,6,12,18$, and $24 \mathrm{mg} / \mathrm{kg})$ and pentazocine $(5,10,20,30$, and $40 \mathrm{mg} / \mathrm{kg}$ ), given alone and in selected combinations, were determined in rats performing under a fixed-ratio 30 schedule of food delivery. Each drug alone produced generally dosedependent decreases in response rates. Combinations typically produced effects identical in direction to, and occasionally greater in magnitude than, those predicted by a simple additive model.

Abuse of the combination of pentazocine and tripelennamine, which is used by addicts as a heroin substitute, recently has become widespread and consequently has evoked considerable attention (Showalter, 1980). Pentazocine, a potent analgesic with both narcotic agonist and antagonist characteristics, possesses known addictive potential (Jasinski, Martin, \& Hoeldtke, 1970). Tripelennamine is an ethylene diamine antihistaminic that blocks $\mathrm{H}_{1}$ receptors; the drug alone has been reported not to have addictive potential (Showalter, 1980).

A recent study demonstrated that the combination of pentazocine and tripelennamine increased low-rate operant responding in rats when behavior was maintained under an interresponse-time-greater-than-t schedule of food delivery (Grossett, Wallace, Picker, \& Poling, in press). In order to further profile the behavioral actions of tripelennamine and pentazocine in combination, the present study examined the effects of these drugs on high-rate operant responding maintained under a fixed-ratio schedule of food delivery.

\section{METHOD}

\section{Subjects and Apparatus}

Four experimentally naive adult male Sprague-Dawley rats, maintained at $80 \%$ of their free-feeding weights, served as subjects. They were individually housed with unlimited access to water in a constantly lighted colony ared with controlled ambient temperature $\left(23^{\circ} \mathrm{C}\right)$.

Four operant conditioning chambers, each equipped with two response levers and a pellet dispenser (see Grossett et al., in press), were used. Programming of experimental events and recording of data were controlled by a PDP-8/A computer (Digital Equipment Corporation, Maynard, MA) equipped with interfacing and software (SUPERSKED) supplied by State Systems, Inc. (Kalamazoo, Mn).

This manuscript is based in part on a doctoral dissertation to be submitted by the first author to Western Michigan Uriversity. Please address reprint requests to Alan Poling, Department of Psychology, Western Michigan University, Kalamazoo, MI 49008.

\section{Procedure}

The rats were first trained to leverpress under a fixed-ratio 1 (FR 1) schedule, in which a 45-mg Noyes (Lancaster, NH) food pellet followed each leverpress. After each rat responded consistently under the FR 1 , the ratio value was gradually lengthened across sessions until an FR 30 schedule was in effect. Each rat was exposed to one 30-min session per day, 6 days per week. The number of responses emitted and food pellets delivered each session were recorded.

The effects of pentazocine and tripelennamine were evaluated alone and in combination. Drugs were given only when an individual subject's response rate under the FR 30 schedule was stable across three consecutive control sessions, in one of which a $1-\mathrm{ml} / \mathrm{kg}$ injection of isotonic saline solution was given intraperitoneally (ip) $30 \mathrm{~min}$ prior to the experimental session. Responding was assumed to be stable when the mean rate of responding varied by less than $10 \%$ across the three sessions. Dose-response curves were determined for five doses of pentazocine alone $(5,10,20,30$, and $40 \mathrm{mg} / \mathrm{kg})$ and five doses of tripelennamine alone $(3,6,12,18$, and $24 \mathrm{mg} / \mathrm{kg})$. Each rat received each dose of pentazocine and tripelennamine on one occasion, in an irregular order. Following testing of the individual drugs, dose-response curves for the two drugs in combination were determined. The effects of three doses of pentazocine $(5,10$, and $20 \mathrm{mg} / \mathrm{kg})$ and three doses of tripelennamine $(3,6$, and $12 \mathrm{mg} / \mathrm{kg})$ were evaluated in all possible combinations. Each rat received each of the nine combined doses once, in an irregular order.

All drug injections were given at a volume of $1 \mathrm{ml} / \mathrm{kg}$. Doses of tripelennamine (Sigma, St. Louis, MO) refer to the total salt; doses of pentazocine (purchased as Talwin ${ }^{\circledR}$ from Winthrop Laboratories, New York, NY) refer to the total base. Both drugs were mixed with isotonic saline solution to obtain the proper injection volume. When given alone and in combination, pentazocine and tripelennamine were given ip $30 \mathrm{~min}$ prior to the experimental session. Thus, conditions of injection were identical during control, single-drug, and multiple-drug sessions.

\section{RESULTS AND DISCUSSION}

Figure 1 shows the effects of pentazocine and tripelennamine alone on group response rates. Repeated measures analyses of variance (Huitema, 1980) indicated that pentazocine $(\mathrm{F}=6.8, \mathrm{p}<.01)$ and tripelennamine $(F=16.1, p<.01)$ alone significantly lowered 


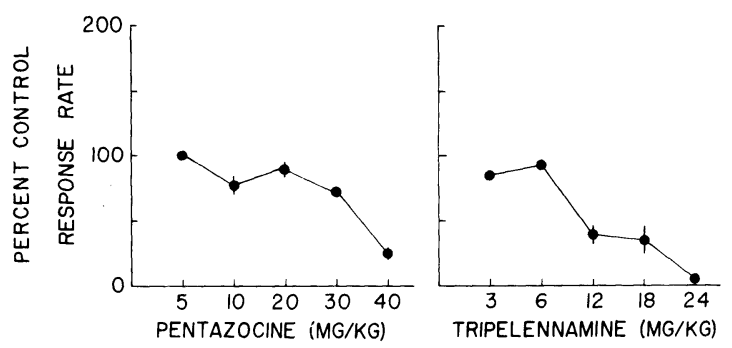

Figure 1. Effects of pentazocine and tripelennamine alone on the mean group response rates of rats responding under an FR 30 schedule of food delivery. Response rates during sessions in which a drug was given are expressed as percentages of the rates obtained across the three control sessions preceding drug administration. Vertical lines indicate \pm 1 standard error (SE). The absence of such lines indicates a SE too small to appear in the figure (i.e., within the data point). Reading from left to right across the figure, mean control response rates (and SEs) were 136.5(25.7), 137.8(24.5), 132.8(25.4), 139.9(25.6), 138.8(24.4), 126.7(15.5), 124.1(12.0), 130.0(25.3), 126.9(22.3), and 132.7 (17.3) responses per minute.

response rates relative to control values. The magnitude of this effect was generally dose dependent for each drug.

Figure 2 depicts the effects of pentazocine and tripelennamine in combination on group response rates. All combined doses significantly decreased group response rates relative to control values (repeated measures analysis of variance, $F=10.44, p<.01$ ). The effects of pentazocine and tripelennamine combinations were similar to, although in six of nine instances slightly

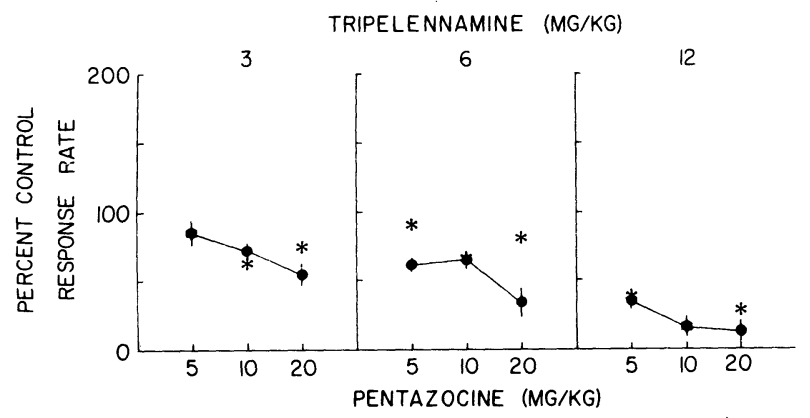

Figure 2. Effects of pentazocine and tripelennamine combinations on mean group response rates of rats responding under an FR 30 schedule of food delivery. Response rates during sessions in which a drug was given are expressed as percentages of the rates obtained across the three control sessions preceding drug administration. Vertical lines indicate \pm 1 standard error (SE). The absence of such lines indicates a SE too small to appear on the figure (i.e., within the data point). Asterisks represent values predicted by an additive model, in which the effects of individual drugs are summated to predict their combined effects. Reading from left to right across the figure, mean control response rates (and SEs) for each drug administration were

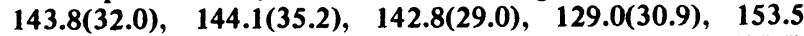
$(27.4), 148.3(27.7), 143.9(30.2), 134.8(27.6)$, and $141.6(25.5)$ responses per minute. greater than, those predicted by a simple additive model. Effects predicted by arithmetic summation of the effects of individual drugs are indicated by asterisks in Figure 2.

Previous studies have shown that pentazocine decreases high-rate operant behavior (McMillan \& Harris, 1972; McMillan \& Morse, 1967). In a recent investigation (Grossett et al., in press), tripelennamine alone appeared to have little effect on low-rate operant responding. However, no reports of the effects of tripelennamine on high-rate operant responding have appeared. In the present study, both pentazocine and tripelennamine alone significantly decreased high-rate operant behavior maintained under a FR 30 schedule of food delivery.

When given together, the effects of the two drugs on high-rate operant behavior were identical in direction to, but occasionally greater in magnitude than, those predicted on the basis of a simple arithmetic summation of the actions of the individual agents. Previous investigations have shown that pentazocine and tripelennamine in combination produce strongly supra-additive effects in a mouse assay of lethality (Poling, Kesselring, Sewell, \& Cleary, 1983; Waller, Katz, \& Morris, 1980). The drugs in combination also reportedly produce weak supra-additive increases in the low-rate operant responding of rats maintained under an interresponse-timegreater-than-t schedule of food delivery (Grossett et al., in press). This finding is similar to that of the present study, in which the effects of the two drugs in combination sometimes were slightly greater in magnitude than would be predicted by a simple additive model. When considered together, the results of the present investigation and those reported by Grossett et al. provide a clear demonstration that the behavioral effects of a drug combination are powerfully determined by control (i.e., nondrug) response rates, as are those of individual agents.

\section{REFERENCES}

Grossett, D., Wallace, S., Picker, M., \& Poling, A. (in press). Tripelennamine and pentazocine alone and in combination: Effects on interresponse-time-greater-than-t responding of rats. Pharmacology, Biochemistry and Behavior.

Huitema, B. (1980). The analysis of covariance and alternatives. New York: Wiley.

Jasinski, D. R., Martin, W. R., \& Hoeldtke, R. D. (1970). Effects of short- and long-term administration of pentazocine in man. Clinical Pharmacology and Therapeutics, 11, 385493.

McMillan, D. E., \& HarRis, L. S. (1972). Behavioral and morphine-antagonist effects of the optical isomers of pentazocine and cyclazocine. Journal of Pharmacology and Experimental Therapeutics, 180, 569-579.

McMillan, D. E., \& Morse, W. H. (1967). Some effects of morphine and morphine antagonists on schedule-controlled behavior. Journal of Pharmacology and Experimental Therapeutics, 157, 175-184. 
Poling, A., Kesselring, J., Sewell, R. G., \& Cleary, J. (1983). Lethality of pentazocine and tripelennamine combinations in mice housed individually and in groups. Pharmacology, Biochemistry and Behavior, 18, 103-105.

Show Alter, C. V. (1980). T's and blues: Abuse of pentazocine and tripelennamine. Journal of the American Medical Association, 244, 1224-1225.
Waller, D. P., Katz, N. L., \& Morris, R. W. (1980). Potentiation of lethality in mice by combinations of pentazocine and tripelennamine. Clinical Toxicology, 16, 17-23.

(Manuscript received for publication January 11, 1984.) 